\title{
Immune Receptors and Co-receptors in Antiviral Innate Immunity in Plants
}

\author{
Bianca C. Gouveia ${ }^{1 \dagger}$, Iara P. Calilit', João Paulo B. Machado ${ }^{1}$, Anésia A. Santos ${ }^{2}$ and \\ Elizabeth P. B. Fontes ${ }^{1 *}$
}

'Department of Biochemistry and Molecular Biology, BIOAGRO, National Institute of Science and Technology in Plant-Pest Interactions, Universidade Federal de Viçosa, Viçosa, Brazil, ${ }^{2}$ Department of General Biology, BIOAGRO, National Institute of Science and Technology in Plant-Pest Interactions, Universidade Federal de Viçosa, Viçosa, Brazil

OPEN ACCESS

Edited by:

Yule Liu,

Tsinghua University, China

Reviewed by:

Xiaorong Tao,

Nanjing Agricultural University, China

Magdalena Krzymowska,

Institute of Biochemistry

and Biophysics (PAN), Poland

${ }^{*}$ Correspondence:

Elizabeth P. B. Fontes

bbfontes@ufv.br

these authors have contributed equally to this work.

Specialty section:

This article was submitted to

Virology,

a section of the journal

Frontiers in Microbiology

Received: 27 September 2016 Accepted: 19 December 2016 Published: 05 January 2017

Citation:

Gouveia BC, Calil IP, Machado JPB, Santos AA and Fontes EPB (2017) Immune Receptors and Co-receptors in Antiviral Innate Immunity in Plants.

Front. Microbiol. 7:2139.

doi: 10.3389/fmicb.2016.02139
Plants respond to pathogens using an innate immune system that is broadly divided into PTI (pathogen-associated molecular pattern- or PAMP-triggered immunity) and ETI (effector-triggered immunity). PTI is activated upon perception of PAMPs, conserved motifs derived from pathogens, by surface membrane-anchored pattern recognition receptors (PRRs). To overcome this first line of defense, pathogens release into plant cells effectors that inhibit PTI and activate effector-triggered susceptibility (ETS). Counteracting this virulence strategy, plant cells synthesize intracellular resistance (R) proteins, which specifically recognize pathogen effectors or avirulence (Avr) factors and activate ETI. These coevolving pathogen virulence strategies and plant resistance mechanisms illustrate evolutionary arms race between pathogen and host, which is integrated into the zigzag model of plant innate immunity. Although antiviral immune concepts have been initially excluded from the zigzag model, recent studies have provided several lines of evidence substantiating the notion that plants deploy the innate immune system to fight viruses in a manner similar to that used for non-viral pathogens. First, most $R$ proteins against viruses so far characterized share structural similarity with antibacterial and antifungal $\mathrm{R}$ gene products and elicit typical ETI-based immune responses. Second, virus-derived PAMPs may activate PTI-like responses through immune co-receptors of plant PTI. Finally, and even more compelling, a viral Avr factor that triggers ETI in resistant genotypes has recently been shown to act as a suppressor of PTI, integrating plant viruses into the co-evolutionary model of hostpathogen interactions, the zigzag model. In this review, we summarize these important progresses, focusing on the potential significance of antiviral immune receptors and coreceptors in plant antiviral innate immunity. In light of the innate immune system, we also discuss a newly uncovered layer of antiviral defense that is specific to plant DNA viruses and relies on transmembrane receptor-mediated translational suppression for defense.

Keywords: resistance genes, receptor NIK1, PAMP-triggered immunity, effector-triggered immunity, antiviral immunity, ETI, PTI, NSP-Interacting kinase 1

\section{INTRODUCTION}

Plants recognize potential pathogens mainly through two classes of distinct immune receptors (Schwessinger and Ronald, 2012; Spoel and Dong, 2012; Zvereva and Pooggin, 2012; Dangl et al., 2013). The first class consists of cell-surface associated pattern recognition receptors (PRRs), which are often represented by receptor-like kinases (RLKs) and receptor-like proteins (RLPs; Figure 1). 
PRRs recognize conserved structural motifs present in microbes, which are known as microbe- or pathogen-associated molecular patterns (MAMPs/PAMPs), or endogenous danger signals released by the plant during wounding or pathogenic attack, which are termed damage-associated molecular patterns (DAMPs; Macho and Zipfel, 2014). Perception of PAMPs by PRRs activates PAMP-triggered immunity (PTI), a transduction signal cascade that culminates with transcriptional reprograming and biosynthesis of specific defense molecules (Hogenhout et al., 2009; Bigeard et al., 2015). Activation of this immune response enables plants to respond rapidly and efficiently to a large range of pathogens (Roux et al., 2014). The second class of immune receptors includes intracellular immune receptors called R proteins (Jones and Dangl, 2006; Tsuda and Katagiri, 2010; Figure 1). These intracellular receptors directly or indirectly recognize effectors secreted by pathogens into the

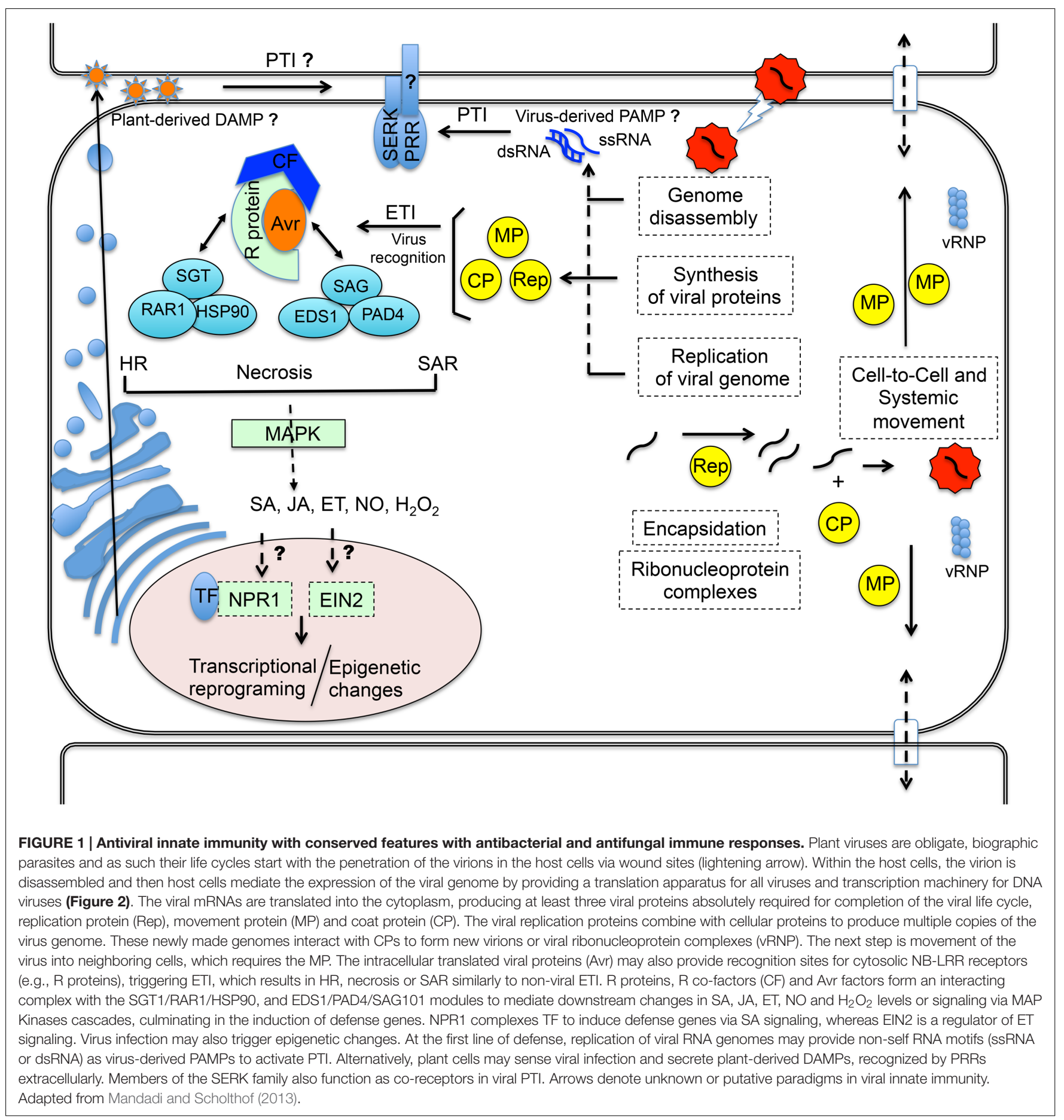


host intracellular environment and activate effector-triggered immunity (ETI; Howden and Huitema, 2012), which is often manifested in the hypersensitive response (HR) associated with rapid cell death, production of reactive oxygen species (ROS) and salicylic acid (SA) as well as expression of defense-related genes (Win et al., 2012). This is considered to be a more robust defense compared to PTI (Coll et al., 2011; Reimer-Michalski and Conrath, 2016). The effectors that are specifically detected by matching $\mathrm{R}$ proteins to activate ETI are termed avirulence (Avr) proteins. Pathogens containing Avr genes are avirulent to plants carrying the cognate $\mathrm{R}$ genes and virulent to plants without the $\mathrm{R}$ genes. Due to the limitation of the coding capacity of viral genomes, virtually all virus proteins, such as replicase, movement proteins (MPs), coat proteins (CPs), can act as Avr determinants. Therefore, virus Avr proteins are usually necessary for successful infection and are almost invariably virulence factors in a susceptible host.

Studies in plant-virus interactions have pioneered the description of paradigms in plant immune response, including the HR and systemic acquired resistance (SAR; Holmes, 1929, 1938; Ross, 1961). Nevertheless, current semantics and concepts regarding plant immunity models were built to fill the findings on bacterial and fungal infections and hence antiviral immune concepts were initially excluded from these models (Jones and Dangl, 2006; Bent and Mackey, 2007; Boller and Felix, 2009; Dodds and Rathjen, 2010; Schwessinger and Ronald, 2012; Spoel and Dong, 2012). Recently, Mandadi and Scholthof (2013) proposed reconciling the differences and perpetuating the analogy between antiviral and anti-non-viral immune concepts into definitions of viral effectors, viral ETI and viral PTI. These definitions, as described below, integrate antiviral immune concepts into current plant immunity models.

Typical bacterial and fungal effectors are delivered into host cells via microbial secretion systems, whereas viral effectors encoded by the viral genome are directly translated into the host cytoplasm. These factors share similar functions because bacterial and fungal effectors interfere with PTI or other immune regulators and viral effectors promote virulence by interfering with host defense pathways. Although not covered in this review, viral suppressors of RNA silencing are also included in this category. Similar to non-viral pathogen effectors, in resistant genotypes, the intracellularly translated viral effectors are recognized by $\mathrm{R}$ proteins, triggering immune responses that often are associated with hallmarks of ETI, such as HR, SA accumulation, ROS production and SAR. Therefore, virus Avr factors, which interfere with defenses, are also referred to as viral effectors, and the immune response they trigger is also referred to as ETI. However, viral ETI is independent with regard to the nature of the immune response, which may or may not be associated with hallmarks of bacterial or fungal ETI. The notion that viruses encode PAMPs recognized by PRRs, such as virus-derived nucleic acids, is well documented in animal systems, and recent evidence has extended the concept of viral PTI to plant-virus interaction systems.

An additional recently uncovered virus-specific defense mechanism relies on suppression of host translation mediated by the transmembrane immune receptor NUCLEAR SHUTTLE PROTEIN-INTERACTING KINASE 1 (NIK1), which was first identified as a virulence target of begomovirus NSP (Figure 2). Activation of NIK1-mediated antiviral signaling leads to translocation of the ribosomal protein L10 (RPL10) to the nucleus, where it interacts with L10-INTERACTING MYB DOMAIN-CONTAINING PROTEIN (LIMYB) to fully repress expression of translational machinery-related genes and global host translation. Begomovirus mRNAs are unable to escape this translational regulatory mechanism of plant cells and hence are not efficiently translated, which compromises infection upon activation of NIK1-mediated defense. Although the NIK1-mediated defense response is remarkably dissimilar from the PTI response, structural components and activation of the NIK1 immune receptor as well as its interaction with virus infection exhibit features reminiscent of the plant innate immunity mechanism.

This review focuses on the concepts of viral ETI and viral PTI, describing antiviral immune receptors and co-receptors involved in antiviral innate immunity in plants. Furthermore, we describe NIK1-mediated antiviral signaling, a newly discovered layer of antiviral defense, which is specific to plant DNA viruses and relies on transmembrane receptor-mediated translational suppression for defense. This latter level of antiviral defense is discussed within the context of the innate immune system.

\section{EFFECTOR-TRIGGERED IMMUNITY IN ANTIVIRAL DEFENSE: R GENE-MEDIATED RESPONSES TO VIRUS INFECTION}

Activation of ETI, involving strain-specific recognition of a virus-encoded effector through direct or indirect interaction with a corresponding resistance gene ( $\mathrm{R}$ gene) product, can lead to the hypersensitive reaction (HR). HR is considered a resistance response against several different pathogens that, to the some extent, occurs through similar mechanisms. Similar to non-viral infections, the HR response during viral infection is initiated by direct or indirect Avr-R interactions and is frequently associated with accumulation of SA in both infected and non-infected tissues (Culver and Padmanabhan, 2007; Carr et al., 2010; Pallas and García, 2011; Mandadi and Scholthof, 2012). HR is also associated with perturbation in $\mathrm{Ca}^{++}$ homeostasis, membrane integrity and activation of caspaselike proteases, such as the vacuolar processing enzyme that is considered an executioner of cell death during HR (Mur et al., 2008). Although cell death is often associated with HRmediated resistance, HR may be uncoupled from resistance, an interpretation that arises from compelling biochemical and genetic studies of Potato virus X (PVX), Tomato bushy stunt virus (TBSV), Cauliflower mosaic virus (CaMV) and Tomato mosaic virus (ToMV; Bendahmane et al., 1999; Chu et al., 2000; Cole et al., 2001; Ishibashi et al., 2007, 2009). For instance, the tomato resistance protein Tm-1 relays resistance against ToMV by inactivating the ToMV replicase protein 


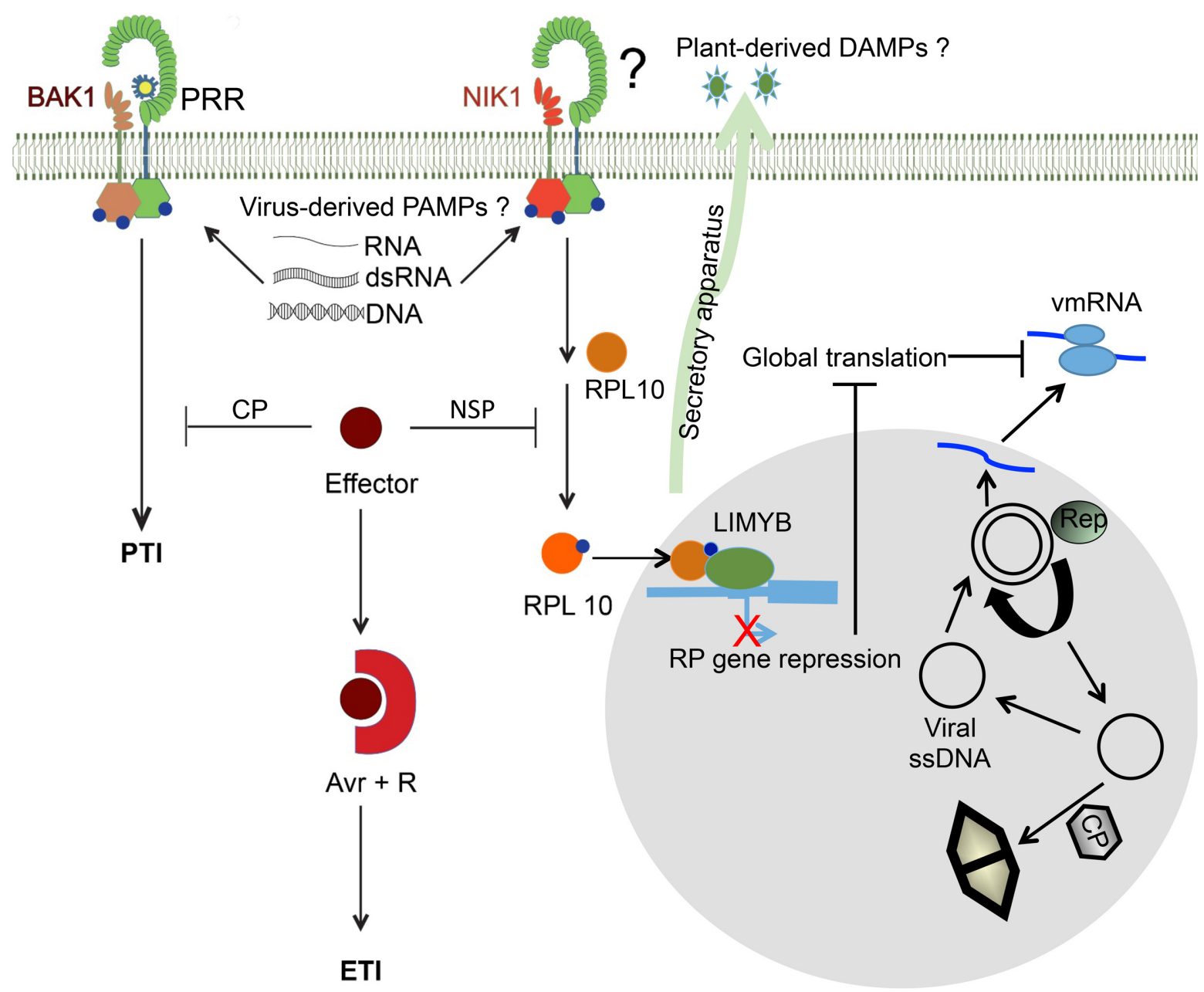

FIGURE 2 | Similarities between viral PTI and NIK1-mediated antiviral signaling. Replication and expression of viral genomes lead to the accumulation of non-self DNA or RNA motifs (virus-derived PAMPs), which may be recognized by PRRs that in turn heteromultimerize with co-receptors (BAK1 or SERK1) to trigger viral PTI. Alternatively, PTI may be activated by endogenous DAMPs, which are induced by virus infection and delivered to the apoplast via the secretory apparatus. In addition to PTI, in the case of DNA viruses (begomoviruses), plant cells may also elicit the translational control branch of the NIK1-mediated antiviral signaling as an innate defense. The mechanism of NIK1 transmembrane receptor activation is unknown. Structural organization and biochemical properties of NIK1 may suggest an activation mechanism dependent on recognition of viral PAMPs or endogenous DAMPs by PRR partners, similarly to a typical viral PTI. In this case, one may consider virus derived-dsDNA as possible PAMPs. The viral single-stranded DNA form begomoviruses replicates via double-stranded DNA intermediates that are transcribed in the nucleus of plant-infected cells. NSP binds to the nascent viral DNA and facilitates its movement to the cytoplasm and acts in concert with the classical MP to transport the viral DNA to the adjacent, uninfected cells. Activation of NIK1 in incompatible interactions promotes phosphorylation and subsequent translocation of RPL10 to the nucleus, where it interacts with LIMYB to fully repress the expression of RP genes, leading to global translation suppression, which also impairs viral mRNA (vmRNA) translation. In begomovirus-host compatible interactions, NSP binds to NIK1 and suppresses its activity. In any case, RNA or DNA viruses, a successful infection implicates in accumulation of virus effectors (for example, CP from PPV and NSP from begomoviruses) to suppress PTI, leading to disease. In resistant genotypes, however, the resistance genes specifically recognize, directly or indirectly, the viral effectors, called avirulence (Avr) factors, activating ETI and conferring resistance. Adapted from Machado et al. (2015).

without eliciting HR-associated cell death (Ishibashi et al., 2007, 2009).

As for non-viral pathogens, most plant antiviral $\mathrm{R}$ genes encode NB-LRR [nucleotide-binding-leucine-rich repeat (LRR)] proteins that mediate resistance via specific (direct or indirect) recognition of a virus Avr factor (Win et al., 2012) (Table 1). Based on their variable N-terminal domain, these plant NB-LRR proteins are further classified into coiled-coil (CC)-NB-LRR or Toll/interleukin 1 receptor-like (TIR)-NB-LRR protein families
(Bonardi et al., 2012). Most of the known antiviral $\mathrm{R}$ proteins are CC-NB-LRR-like, whereas only a small number belong to the TIR-NB-LRR class (Zvereva and Pooggin, 2012; de Ronde et al., 2014). Recognition of effectors by $R$ proteins may occur through direct ligand-receptor interactions (gene-for-gene model; Flor, 1971 ) or through indirect interactions (Guard Model; Jones and Dangl, 2006; Oßwald et al., 2014). In the Guard Model, the resistance protein guards a target host protein, the guardee, and perceives alterations in this target protein upon interaction 
TABLE 1 | Plant antiviral NB-LRR resistance genes and the cognate avirulence determinants.

\begin{tabular}{|c|c|c|c|c|c|}
\hline Gene & Plant & $\begin{array}{l}\mathbf{R} \text { protein } \\
\text { signature }\end{array}$ & Virus & Avr factor & Reference \\
\hline$N$ & Nicotiana glutinosa & TIR-NB-LRR & $\begin{array}{l}\text { Tobacco mosaic virus } \\
\text { (TMV) }\end{array}$ & Replicase & $\begin{array}{l}\text { Whitham et al., 1994; } \\
\text { Padgett et al., } 1997\end{array}$ \\
\hline$R \times 1$ & Solanum tuberosum & CC-NB-LRR & Potato virus $X(P \vee X)$ & Coat Protein & Bendahmane et al., 1999 \\
\hline$R \times 2$ & S. tuberosum & CC-NB-LRR & $P V X$ & Coat Protein & Bendahmane et al., 2000 \\
\hline HRT & $\begin{array}{l}\text { Arabidopsis thaliana } \\
\text { ecotype Dijon-17 }\end{array}$ & CC-NB-LRR & Turnip crinkle virus (TCV) & Coat Protein & $\begin{array}{l}\text { Cooley et al., } 2000 \text {; } \\
\text { Ren et al., } 2000\end{array}$ \\
\hline$R C Y 1$ & A. thaliana ecotype C24 & CC-NB-LRR & $\begin{array}{l}\text { Cucumber mosaic virus } \\
\text { strain y }\end{array}$ & Coat Protein & Takahashi et al., 2001, 2002 \\
\hline Sw-5 & Solanum peruvianum & $\begin{array}{l}\text { SD-CC-NB- } \\
\text { LRR }\end{array}$ & Tomato spotted wilt virus & Movement protein (NS) & $\begin{array}{l}\text { Brommonschenkel et al., 2000; } \\
\text { Spassova et al., 2001; } \\
\text { Hallwass et al., 2014; } \\
\text { Peiro et al., } 2014\end{array}$ \\
\hline$Y-1$ & S. tuberosum & TIR-NB-LRR & Potato virus $Y$ & $?$ & Vidal et al., 2002 \\
\hline$T m-22$ & Solanum lycopersicum & CC-NB-LRR & Tomato mosaic virus (ToMV) & Movement protein & Lanfermeijer et al., 2003 \\
\hline BcTuR3 & Brassica campestris & TIR-NB-LRR & Turnip mosaic virus & $?$ & Ma et al., 2010 \\
\hline Rsv1 & Glycine max & CC-NB-LRR & Soybean mosaic virus & P3 + HC-Pro & $\begin{array}{l}\text { Hayes et al., 2004; } \\
\text { Wen et al., } 2013\end{array}$ \\
\hline Pv1 & Cucumis melo & TIR-NB-LRR & Papaya ringspot virus & $?$ & Anagnostou et al., 2000 \\
\hline Pv2 & Cucumis melo & TIR-NB-LRR & Papaya ringspot virus & $?$ & Brotman et al., 2013 \\
\hline Cv (locus) & Poncirus trifoliata & CC-NB-LRR & Citrus tristeza virus & $?$ & Yang et al., 2003 \\
\hline CYR1 & Vigna mungo & CC-NB-LRR & $\begin{array}{l}\text { Mungbean yellow mosaic } \\
\text { virus }\end{array}$ & Coat Protein & Maiti et al., 2012 \\
\hline Pvr4 & Capsicum annuum & CC-NB-LRR & $\begin{array}{l}\text { Potato virus } Y \\
\text { Pepper mottle virus }\end{array}$ & $\begin{array}{l}\text { RNA-dependent RNA } \\
\text { polymerase (NIb) }\end{array}$ & Kim et al., 2015, 2016 \\
\hline Tsw & Capsicum chinense & CC-NB-LRR & Tomato spotted wilt virus & $\begin{array}{l}\text { NSs RNA silencing } \\
\text { suppressor }\end{array}$ & $\begin{array}{l}\text { Margaria et al., 2007; } \\
\text { Ronde et al., 2013, 2014; } \\
\text { Kim et al., } 2016\end{array}$ \\
\hline
\end{tabular}

Avr, avirulence; CC, coiled-coil; NB, nucleotide binding; LRR, leucine-rich repeat; SD, solanaceous-specific domain; TIR, Toll/interleukin 1 receptor-like.

with the pathogen effectors. Therefore, the modification of the guardee by the effector causes activation of the $\mathrm{R}$ protein to initiate a resistance response. Implicit in the Guard Model is the notion that the guarded effector target is indispensable for the virulence function of the effector protein in the absence of the cognate $\mathrm{R}$ protein (Dangl and Jones, 2001; Jones and Dangl, 2006). Alternatively, in the Decoy Model, a decoy (effector target mimic) evolved to act as a molecular sensor to only detect a pathogen without having any other role in the basic cellular machinery of the host (Van der Hoorn and Kamoun, 2008). Therefore, effector alteration of the decoy triggers innate immunity in plants that carry the cognate $\mathrm{R}$ protein but does not result in enhanced pathogen fitness in plants that lack the $\mathrm{R}$ protein.

The R signaling cascade in plant-virus interactions consists of rapid activation of MAP kinases and involvement of molecular chaperone complexes controlling $\mathrm{R}$ protein stabilization and destabilization (Kadota and Shirasu, 2012; Hoser et al., 2013). Convergence between viral and non-viral ETI is observed at the chaperone protein complex containing HEAT SHOCK PROTEIN 90 (HSP90), SUPPRESSOR OF THE G2 ALLELE OF SKP1 (SGT1) and REQUIRED FOR MLA12 RESISTANCE1 (RAR1). The HSP90/RAR1/SGT1 chaperone complex contributes to the stability and proper folding of $\mathrm{R}$ proteins during activation, mediating downstream MAP kinase activation, changes in defense gene expression and hormone levels (Liu et al., 2004; Dodds and Rathjen, 2010). Examples of R proteins against viruses that use the HSP90/RAR1/SGT1signaling module to mediate antiviral resistance are the $\mathrm{N}$ protein and $\mathrm{Rx}$ protein, which confer resistance against Tobacco mosaic virus (TMV) and PVX, respectively (Table 1) (Liu et al., 2004; Botër et al., 2007). Another functional module comprising ENHANCED DISEASE SUSCEPTIBILITY1 (EDS1; Aarts et al., 1998; Falk et al., 1999), PHYTOALEXIN DEFICIENT4 (PAD4; Feys et al., 2001, 2005) and SENESCENCE-ASSOCIATED GENE101 (SAG101) mediates HR against viral and nonviral pathogens in a similar manner. In Arabidopsis, the EDS1/PAD4/SAG101 complex regulates HRT-mediated resistance against Turnip crinkle virus (TCV; Table 1) (Zhu et al., 2011). The HRT-mediated resistance also requires a functional SA-mediated signaling pathway (Chandra-Shekara et al., 2004). Disruption of SA signaling compromises HRTmediated resistance without affecting HRT-mediated HR, providing further evidence that $\mathrm{HR}$ and resistance, albeit closely related, are unlinked processes. Therefore, virus-triggered ETI responses also involve functional SGT1/RAR1/HSP90 (Liu et al., 2004) and EDS1/PAD4/SAG101 (Zhu et al., 2011) protein complexes.

The tobacco $N$ gene (for necrotic-type response), which confers resistance against TMV and encodes a TIR-NB-LRR 
protein, was the first identified R gene (Holmes, 1938; Whitham et al., 1994). TMV is a positive-sense single-stranded RNA virus of $6.3-6.5 \mathrm{~kb}$ that encodes at least four proteins (Goelet et al., 1982; Osman and Buck, 1996). They include a 126-kDa replicase (with methyltransferase and RNA helicase domains), which is encoded by the $5^{\prime} \mathrm{ORF}$ of TMV and is directly translated from genomic RNA; the stop codon of which is read through to give a $183-\mathrm{KDa}$ RNA-dependent RNA polymerase (RDR). The other two viral proteins, a MP and a capsid protein (CP), are expressed from separate subgenomic RNAs. The $\mathrm{N}$ resistance protein directly interacts with the helicase domain (the p50 effector) of TMV replicase to trigger resistance (Ueda et al., 2006). In fact, ectopic expression of the C-terminal $50 \mathrm{kDa}$ portion $(\mathrm{p} 50)$ of the $126 \mathrm{kDa}$ replicase is sufficient to induce $\mathrm{HR}$ in tobacco carrying the $N$ gene (Erickson et al., 1999). Full resistance to TMV, however, depends on $\mathrm{N}$ receptor-interacting protein 1 (NRIP1), which is recruited from chloroplasts to the cytoplasm and nucleus by the p50 effector and interacts directly with the $\mathrm{N}$ resistance protein (Caplan et al., 2008). The nuclear localization of the $\mathrm{N}$ resistance protein, which has been demonstrated to be critical for N-mediated resistance, is controlled by upstream events of receptor activation (Burch-Smith et al., 2007; Hoser et al., 2013). As a plant NB-LRR, the N protein requires the conserved chaperone complex consisting of HSP90, RAR1 and SGT for proper folding, accumulation and regulation (Liu et al., 2004). The assembly of this chaperone complex with the $\mathrm{N}$ protein occurs in the cytoplasm and SGT controls the nucleocytoplasmic partitioning of the immune receptor (Hoser et al., 2013). Upon TMV infection, p50 binds first to the TIR domain and then to the $\mathrm{NB}$ and LRR domains of the $\mathrm{N}$ protein leading to conformational changes and oligomerization of the immune receptor (Mestre and Baulcombe, 2006). Phosphorylation of SGT1 by an activated SIPK, a tobacco MAPK6 homolog, shifts the balance toward its nuclear distribution and consequently the $\mathrm{N}$ receptor complex is distributed to the nucleus (BurchSmith et al., 2007; Hoser et al., 2013). Within the nucleus, N protein interacts with transcriptional factors (TFs) to modulate the expression of defense-related genes. The SQUAMOSA PROMOTER BINDING PROTEIN (SBP)-domain transcription factor SPL6 is an example of TF that interacts with the $\mathrm{N}$ immune receptor and positively regulates a subset of defense genes (Padmanabhan et al., 2013). This association is detected only when the TMV effector, p50, is present in the cell and is required for N-mediated resistance. SPL6 from Arabidopsis also functions in resistance against the bacterial pathogen Pseudomonas syringae expressing the AvrRps4 effector, as SPL6 is required for the R protein RPS4-mediated resistance (Padmanabhan et al., 2013). Therefore, the SPL6-mediated modulation of defense gene expression represents another convergent point in $\mathrm{R}$-mediated resistance against both viruses and bacteria.

The $R x$ gene in potato encodes a well-characterized representative of the CC-NB-LRR class of $\mathrm{R}$ proteins, which mediates extreme resistance against PVX elicited by the viral CP. PVX is also a monopartite positive-sense single-stranded RNA virus (Huisman et al., 1988). Unlike other disease resistance responses, this extreme resistance is not associated with HR at the site of infection but rather is associated with an early arrest of viral accumulation in single cells (Bendahmane et al., 1999). The $\mathrm{Rx}$ protein also associates with the molecular chaperone HSP90 and its signaling proteins SGT1 and RAR1 to modulate the innate immune response in plants (Botër et al., 2007). The cochaperone SGT1 also interferes with the nucleocytoplasmic distribution of $\mathrm{Rx}$ protein (Slootweg et al., 2010; Hoser et al., 2014). Accordingly, silencing the cochaperone SGT1 impaired the accumulation of Rxl protein in the nucleus and $\mathrm{Rx}$ distribution exactly mirrored that of ectopic AtSGT1b variants with forced cytoplasmic or nuclear localization. The $\mathrm{Rx}$ nucleocytoplasmic partitioning is also controlled by the Rx interacting partner RanGAP2 (Tameling et al., 2010). The Rx N-terminal CC domain interacts intramolecularly with the $\mathrm{Rx}$ NB-LRR region and intermolecularly with the $\mathrm{Rx}$ cofactor RanGAP2 (Ran GTPase-activating protein 2; Rairdan et al., 2008; Tameling et al., 2010). In fact, the crystal structure of the CC domain of $\mathrm{Rx}$ in complex with the Trp-Pro-Pro (WPP) domain of RanGAP2 reveals that the $\mathrm{Rx}$ CC domain forms a heterodimer with RanGAP2, which may prevent $\mathrm{Rx}$ self-association (Hao et al., 2013). The C-terminus of the LRR domain is thought to be involved in specific recognition of the viral effector, $\mathrm{CP}$, although direct interaction between $\mathrm{CP}$ and $\mathrm{Rx}$ has not been demonstrated (Bendahmane et al., 1995; Dangl and Jones, 2001; Farnham and Baulcombe, 2006; Candresse et al., 2010). The Rx-interacting protein RanGAP2 controls $\mathrm{Rx}$ nucleocytoplasmic distribution and can act as a cytoplasmic retention factor for Rx. CP of PVX is recognized in the cytosol, and signaling is also activated in this compartment. Concentrating $\mathrm{Rx}$ in the cytosol via RanGAP2 overexpression enhances resistance signaling, whereas sequestering $\mathrm{Rx}$ in the nucleus through interaction with a nuclear-localized version of RanGAP2 inhibits resistance signaling (Slootweg et al., 2010; Tameling et al., 2010). However, nuclear export signal-mediated expulsion of $\mathrm{Rx}$ from the nucleus moderately reduced resistance, indicating that the nuclear pool of $\mathrm{Rx}$ also functions in immunity. These results demonstrate that both nuclear and cytoplasmic pools of NB-LRR Rx1 are necessary for full immune responses to PVX. Therefore, in both $\mathrm{Rx}$ mediated resistance and $\mathrm{N}$-mediated resistance, the $\mathrm{R}$ protein is activated in the cytoplasm, yet full functionality of the $\mathrm{Rx}$ and $\mathrm{N} \mathrm{R}$ proteins depends on their nucleocytoplasmic distribution.

A few dominant resistance genes encoding the non-NB-LRR class of proteins have been characterized; these proteins have been found to function as sensors of virus infection but do not induce typical ETI-like defense responses, such as HR (Table 2). One such example is the tomato Tm-1 gene, which confers dominant resistance to ToMV and contains two conserved domains: an uncharacterized N-terminal region (residues M1K431) and a TIM-barrel-like C-terminal domain (residues T484E754; Ishibashi et al., 2012, 2014; Yang et al., 2016). Tm-1 binds to ToMV replication proteins and inhibits ToMV multiplication without inducing a defense response: binding of Tm-1 to ToMV replication proteins inhibits the RNA-dependent RNA replication of ToMV and replication complex assembly on membranes that 
TABLE 2 | Plant antiviral non-NB-LRR resistance genes and the cognate avirulence determinants.

\begin{tabular}{|c|c|c|c|c|c|}
\hline Gene & Plant & $\mathbf{R}$ protein signature & Virus & Avr determinant? & Reference \\
\hline$J A X 1$ & Arabidopsis thaliana & Jacalin-like [lectin gene] & $\begin{array}{l}\text { Broad resistance against } \\
\text { potexvirus }\end{array}$ & $?$ & Yamaji et al., 2012 \\
\hline$R T M 1$ & Arabidopsis thaliana & Jacalin-like & Tobacco etch virus & Coat Protein & Chisholm et al., 2000 \\
\hline RTM2 & Arabidopsis thaliana & Jacalin-like & Plum pox virus & Coat Protein & $\begin{array}{l}\text { Whitham et al., 2000; } \\
\text { Decroocq et al., } 2009\end{array}$ \\
\hline$T y-1, T y-3$ & Solanum chilense & RDR & Tomato yellow leaf curl virus & $?$ & $\begin{array}{l}\text { Verlaan et al., 2013; } \\
\text { Butterbach et al., } 2014\end{array}$ \\
\hline$T m-1$ & Solanum hirsutum & $\begin{array}{l}\text { TIM-barrel-like domain } \\
\text { protein }\end{array}$ & ToMV & Replicase, Helicase domain & $\begin{array}{l}\text { Ishibashi et al., 2007; } \\
\text { Kato et al., } 2013\end{array}$ \\
\hline
\end{tabular}

Avr, avirulence; RDR, RNA-dependent RNA polymerase.

precedes negative-strand RNA synthesis (Ishibashi and Ishikawa, 2013, 2014). Another recently characterized example of non-NBLRR $R$ proteins is the sensor proteins Ty-1 and Ty-3, which confer resistance to Tomato yellow Leaf Curl Virus (TYLCV). The $T y-1$ and $T y-3$ genes are allelic and code for an RDR of the RDRc type, which has an atypical DFDGD motif in the catalytic domain (Verlaan et al., 2013). The mechanism of resistance is completely uncoupled from ETI and appears to be linked to the RNA silencing strategy of antiviral defense (Butterbach et al., 2014). Accordingly, Ty-1/Ty-3 plants display enhanced siRNA levels that coincide with hypermethylation of the TYLCV V1 (CP) promoter, indicating that Ty-1-based resistance against TYLCV involves enhanced transcriptional gene silencing.

In summary, most antiviral dominant resistance genes so far characterized encode typical NB-LRR R proteins (Table 1), which specifically recognize viral effectors or Avr factors and utilize signaling modules such as SGT1/RAR1/HSP90 and EDS1/PAD4/SAG101 complexes to mediate resistance responses, similar to non-viral pathogens. Therefore, plants appear to have evolved strategies and signaling modules to defend themselves against a large spectrum of pathogen types, such as bacteria, viruses and fungi. This interpretation allows us to integrate some aspects of the antiviral immune concepts into the typical bacterial and fungal immunity models to classify viral effectors and viral ETI.

\section{PAMP-TRIGGERED IMMUNITY IN ANTIVIRAL DEFENSES: CO-RECEPTORS PAVE THE WAY}

Plant innate defense responses are also activated upon perception of conserved PAMPs, which are pathogen-derived conserved motifs. In addition, endogenous molecules released by the host during pathogenic attack or wounding, which are known as DAMPs, can also elicit plant defense (Zipfel, 2014). Detection of different PAMPs/DAMPs by the corresponding PRRs at the plasma membrane activates signaling cascades, leading to transcriptional and physiological changes in host cells that prevent pathogen infection and establish PTI (Jones and Dangl, 2006; Macho and Zipfel, 2014; Bartels and Boller, 2015). In plants, PRRs are represented by RLKs and RLPs located at the cell surface, both of which require a coreceptor to form an active complex and initiate signaling (Machado et al., 2015). The best characterized co-receptors for PRR are members of LRR subfamily II of the RLK superfamily (LRRII-RLK subfamily). This family is represented by 13 members in the Arabidopsis genome, which can be divided into three closely related clusters: one representing five SOMATIC EMBRYOGENESIS RECEPTOR KINASES (SERK15), a cluster of LRR-RLKs of unknown function and a cluster of NUCLEAR-SHUTTLE PROTEIN-INTERACTING KINASES (NIK1-3; Zhang et al., 2006; Sakamoto et al., 2012). Among SERKs, SERK3, which is also termed BRASSINOSTEROID INSENSITIVE 1 (BRI1)-ASSOCIATED KINASE 1 (BAK1), is the most well-characterized subfamily member. SERK3 functions as a co-receptor of several PRRs, such as FLAGELLIN SENSING 2 (FLS2), ELONGATION FACTOR-thermo unstable (EF-Tu) receptor (EFR) or PEP1 receptor 1 (PEPR1), which perceive specific PAMPs/DAMPs and trigger or amplify bacterial/fungal PTI (Chinchilla et al., 2007; Heese et al., 2007; Roux et al., 2011; Wang et al., 2014). Upon PAMP perception, FLS2 and EFR form a ligand-induced complex with BAK1, which leads to rapid phosphorylation of both proteins (Chinchilla et al., 2007; Heese et al., 2007; Roux et al., 2011; Sun et al., 2013) and activation of immune responses, including production of ROS by the NADPH oxidase RBOHD, activation of the mitogen-activated protein kinase (MAPK) cascade, transcriptional reprogramming of defense genes and immunity to pathogens (Kadota et al., 2014; Li et al., 2014; Macho and Zipfel, 2014).

The mechanism of PTI in virus-host interactions is well characterized in animals. One of the best studied PRRs in mammals, Toll-like receptors (TLR), have important roles in antiviral defense via recognition of a different range of MAMPs, such viral RNA and DNA (Song and Lee, 2012). In contrast, the PTI pathway in plants remains unclear with regard to resistance against viruses, although studies describing an association of PTI in antiviral immunity have been recently reported (Yang et al., 2010; Kørner et al., 2013; Nicaise, 2014; Machado et al., 2015; Nicaise and Candresse, 2016; Niehl et al., 2016). Indeed, a complex set of typical PTI responses is induced in plants upon virus infection, including SA accumulation, ROS production, ion fluxes, defense gene (e.g., PR-1) activation, and callose deposition (for a review, see Nicaise, 2014). The PRR co-receptors BAK1 
or BAK1-LIKE1 (BKK1) are required for antiviral immunity in Arabidopsis, and loss-of-function mutations in BAK1 and $B K K 1$ result in enhanced susceptibility to TCV infection (Yang et al., 2010). Consistently, Arabidopsis bak-1 mutants show increased susceptibility to three different RNA viruses, and crude extracts of virus-infected leaf tissues induce typical PTI responses in a BAK1-dependent manner (Kørner et al., 2013). The Arabidopsis double mutant bak1-5 bkk1 displays increased viral accumulation when inoculated with Plum pox virus (PPV; Nicaise and Candresse, 2016). Furthermore, MAPK4, a negative regulator of plant PTI signaling, suppresses soybean defense against Bean pod mottle virus (BPMV; Liu et al., 2011), and chitosan, a deacetylated chitin derivative elicitor, is able to stimulate the plant immune response against viruses (Iriti and Varoti, 2014).

The current data suggest that viral components can act as PAMPs but do not eliminate the possibility that DAMPs produced in response to virus can potentially elicit PTI-based antiviral responses in plants. Recently, double-stranded RNA (dsRNA) and virus-derived dsRNA have been shown to function as viral PAMPs in Arabidopsis and to induce the PTI pathway (Niehl et al., 2016). Indeed, application of dsRNA to Arabidopsis leaf disks resulted in the induction of typical PTI responses, including MAPK activation, ethylene synthesis and defense gene expression. Furthermore, dsRNA treatment confers protection against viruses because plants inoculated with the synthetic dsRNA analog polyinosinic-polycytidylic acid, poly(I:C) together with Oilseed rape mosaic virus (ORMV) showed significantly reduced viral accumulation in treated leaves. Interestingly, dsRNA-mediated PTI appears to be independent of the RNA silencing pathway but does involve the co-receptor kinase SERK1. These findings relate membrane-associated signaling events with dsRNA-mediated PTI in plants (Niehl et al., 2016). Although plasma membrane-localized co-receptors of PRRs, such as BAK1, BKK1 and SERK1, have been shown to be involved in viral PTI, it remains to be determined how intracellular pathogens, which deliver PAMPs intracellularly, are perceived extracellularly.

The PTI pathway also contributes to antiviral immunity against PPV in Arabidopsis (Nicaise and Candresse, 2016). As a counteraction strategy, the CP from PPV appears to act as a PTI suppressor, impairing early immune responses such as the oxidative burst and enhanced expression of PTI-associated marker genes in planta during infection (Nicaise and Candresse, 2016). Therefore, PPV CP displays a virulence function that acts at the PTI level and antagonizes the Avr functions of many viral recognized by antiviral $\mathrm{R}$ proteins during elicitation of ETI (Table 1). These observations suggest that plant viruses also fit into the zigzag model of co-evolving pathogenic virulence strategies and plant defense responses that shape the twobranched innate immune system (Jones and Dangl, 2006).

Collectively, these data suggest the existence of PTI signaling mechanism targeting plant viruses and may represent a conserved process between plants and animals. Identification of PRR-mediated pathways as well as characterization of nucleic acid-sensing PRRs will shed light on the mechanism by which PTI is elicited in plants and its role in antiviral resistance.

\section{TRANSMEMBRANE RECEPTOR-MEDIATED TRANSLATIONAL SUPPRESSION IN ANTIVIRAL IMMUNITY: UNIQUE AND SHARED PTI-LIKE FEATURES OF THE NIK1-MEDIATED ANTIVIRAL RESPONSE}

The transmembrane receptor NIK was first identified as a virulence target of Nuclear Shuttle Protein (NSP) from Begomovirus, the largest genus of the Geminiviridae family (Fontes et al., 2004; Mariano et al., 2004). Similar to the PTI coreceptors BAK1 and SERK1, NIK receptors (NIK1, NIK2 and NIK3) belong to the LRRII-RLK subfamily and are involved in plant defenses against viruses (Fontes et al., 2004). Nevertheless, the mechanism by which NIK1 transduces the antiviral signal is completely different from the typical PTI signaling mediated by BAK1 or SERK1 and PRRs. Nonetheless, some similarities between these transduction pathways with regard to receptor activation, suppression and association with ETI have been observed (Machado et al., 2015, Figure 2).

NUCLEAR SHUTTLE PROTEIN-INTERACTING KINASE 1-mediated antiviral signaling is activated upon perception of begomovirus infection, which leads to phosphorylation of the NIK1 kinase at key threonine residues at positions 468 and 474 (Santos et al., 2009; Zorzatto et al., 2015). Thr-468 and Thr-474 are located within the conserved activation loop and align to the same positions as conserved BAK1 residues Thr449 and Thr-455 and SERK1 residues Thr-462 and Thr-468, which are intramolecular targets for BAK1 and SERK1 kinase activation (Shah et al., 2001; Wang et al., 2005, 2008; Yun et al., 2009). Phosphorylation of the functional analogs NIK1 Thr-474, SERK1 Thr-468 and BAK1 Thr-455 is essential for receptor/co-receptor signaling, which may underscore a similar mechanism for activation (Shah et al., 2001; Wang et al., 2008; Santos et al., 2009; Yun et al., 2009; Brustolini et al., 2015). Nevertheless, unlike BAK1 or SERK1, phosphorylation at NIK1 Thr-474 leads to phosphorylation at Thr-469, which has an inhibitory effect, thereby providing a mechanism by which NIK1 modulates the extent of auto- and substrate phosphorylation. Although NIK1 is activated upon perception of virus infection, the molecular bases of such elicitation are unknown. Indeed, there is a complete lack of information with respect to the nature and identity of possible ligands or mechanisms that trigger or stabilize NIK1 dimerization or multimerization with receptors. Because viruses are intracellular pathogens and may not have access to the apoplast, it remains to be determined how the NIK1 extracellular domain, which is expected to drive ligand-dependent oligomerization of receptors and co-receptors, senses viruses intracellularly. Possible ligands that could perform this function are DAMPs, which would be secreted by plant cells upon virus perception. Alternatively, viral nucleic acidderived PAMPs could intracellularly activate NIK1 kinase, a mechanism that would resemble virus-derived dsRNA-mediated activation of mammalian intracellular protein kinase R (PKR; Balachandran et al., 2000). Virus-derived nucleic acid PAMPs 
could also activate NIK1-associated nucleic acid-sensing PRRs in endosomes derived from receptor internalization via endocytic pathways. In plant cells, the PRRs FLS2, ERR and PEPR have been shown to be internalized in a clathrin-dependent manner. Endocytosis requires the co-receptor BAK1 and depends on receptor activation (Mbengue et al., 2016). In a similar manner, the Avr factor Avr4 induces association of Cf-4 RLP with BAK1 to initiate receptor endocytosis and plant immunity (Postma et al., 2016).

In general, ligand-dependent phosphorylation and activation of RLKs require homo or heterodimerization of the receptors. In the case of BAK1 and SERK1, compelling evidence has revealed that they function primarily as co-receptors for receptor signaling not only in defense but also in development (Ma et al., 2016). As a member of the LRRII-RLK subfamily sharing conserved structural organization and biochemical activation properties with SERKs, NIK1 may also function as a co-receptor in immune active complexes. However, NIK1-containing antiviral signaling complexes have not been isolated, and a receptor partner for NIK1 has yet to be identified.

Begomovirus NSP binds in vitro and in vivo with the kinase domain of NIK1 to suppress NIK1 activity (Fontes et al., 2004; Brustolini et al., 2015). The NSP binding site corresponds to an 80-amino acid stretch (positions 422-502) of NIK1 that encompasses the putative Ser/Thr kinase active site (subdomain VIb-HrDvKssNxLLD) and the activation loop (subdomain VIIDFGAk/rx, plus subdomain VIII-GtxGyiaPEY; Fontes et al., 2004). Binding of NSP to the kinase domain promotes steric constraints that impair intermolecular phosphorylation at Thr474 within the A-loop of NIK1, thereby suppressing its kinase activity. The NSP-mediated suppression of NIK1 kinase prevents activation of the NIK-mediated pathway and hence enhances the pathogenicity of begomoviruses in their hosts (Santos et al., 2009, 2010). In addition to acting as a virulence factor suppressing NIK1-mediated antiviral signaling, NSP from the begomovirus Bean dwarf mosaic virus (BDMV) has been demonstrated to function as an Avr gene and elicit HR in Phaseolus vulgaris (Garrido-Ramirez and Gilbertson, 1998). According to the zigzag evolutionary model of plant innate immunity (Jones and Dangl, 2006), the involvement and activation of ETI in plant-virus interactions (NSP in resistant bean genotypes) is conceptually associated with successful PTI inhibition (NIK1 signaling) by a viral effector (NSP). This interpretation further substantiates the notion that NIK1-mediated antiviral signaling shows features of PTI-like mechanisms.

Despite similarities in the activation and suppression mechanisms of PTI and NIK1-mediated antiviral signaling, the downstream events of NIK1 activation are quite distinct from the typical PTI response. In fact, activation of NIK1 signaling by constitutive or inducible expression of the gain-of-function T474D NIK1 mutant, which is not inhibited by viral NSP, results in a massive down-regulation of translation machinery-related genes, suppression of host global translation and enhanced broad-spectrum tolerance to begomoviruses in Arabidopsis and tomato (Brustolini et al., 2015; Zorzatto et al., 2015). T474D-mediated suppression of global translation is associated with a decrease in host and viral mRNA in actively translating polysomes. Therefore, begomovirus is not capable of sustaining high levels of viral mRNA translation in T474D-expressing lines, indicating that suppression of global protein synthesis may effectively protect plant cells against DNA viruses.

Progress toward deciphering the mechanism of the translational control branch of NIK1 signaling includes identification of the downstream effectors, RPL10 and LIMYB (Rocha et al., 2008; Zorzatto et al., 2015). RPL10 was isolated based on its capacity to interact with NIK1 and was genetically and biochemically linked to the NIK1-mediated signaling pathway (Carvalho et al., 2008; Rocha et al., 2008). Consistent with a role for RPL10 in antiviral defense, loss of RPL10 function recapitulates the nik 1 enhanced susceptibility phenotype to begomovirus infection, as rpl10 knockout lines develop severe symptoms similar to those of nik 1 and display a similar infection rate (Carvalho et al., 2008; Rocha et al., 2008). NIK1 activation mediates RPL10 phosphorylation and consequent translocation of the RP from the cytoplasm to the nucleus. The regulated nucleocytoplasmic shuttling of RPL10 depends on NIK1 kinase activity and on the phosphorylation status of the RP (Carvalho et al., 2008). Mutations that impact NIK1 activity similarly affect the capacity of NIK1 to mediate translocation of RPL10 to the nucleus and to transduce an antiviral signal. In the nucleus, RPL10 interacts with LIMYB to form a transcriptionrepressing complex that specifically down-regulates expression of translational machinery-related genes, such as RP genes. This down-regulation of RP genes results in global suppression of host translation and enhanced tolerance to begomoviruses. Expression of the gain-of-function T474D mutant also results in repression of the same set of LIMYB-regulated RP genes, but $\mathrm{T} 474 \mathrm{D}$ requires the function of LIMYB for RP repression. In addition, loss of LIMYB function releases the repression of translation-related genes and increases susceptibility to Cabbage leaf curl virus (CaLCuV) infection (Zorzatto et al., 2015). Collectively, these results provide both genetic and biochemical evidence that LIMYB functions as a downstream component of the NIK1-mediated signaling pathway linking NIK1 activation to global translation suppression and tolerance to begomoviruses.

Although NIK1 is structurally similar to SERKs, the mechanism of NIK1-mediated antiviral defense is distinct from that of BAK1-mediated PTI. The current model for NIK1mediated antiviral signaling states that, in response to virus infection, NIK1 undergoes homo- or heterodimerization to promote phosphorylation of the activation loop (Figure 2). Activated NIK1 mediates phosphorylation and consequent translocation of RPL10 to the nucleus, where it interacts with LIMYB to fully repress RP gene expression. Prolonged downregulation of RP gene expression leads to suppression of global host translation. DNA viruses, such as begomoviruses, cannot escape this translational regulatory mechanism of plant cells, and viral mRNAs are not translated efficiently, thereby compromising infection. NSP acts as a virulence factor and suppresses the kinase activity of NIK1 to overcome the NIK1-mediated immune response. NSP from the begomovirus BDMV has also been shown to function as an Avr factor that activates typical ETI responses in resistant bean genotypes. Therefore, NSP may link the suppression of NIK1 signaling with activation of ETI 
responses in accordance with the zigzag evolutionary model of plant innate immunity, although the NIK1-mediated antiviral signaling may represent a new evolved branch of plant antiviral immunity, which relies on suppression of translation for defense.

\section{CONCLUSION}

Innate immunity against plant viruses and its underlying mechanisms have attracted the attention of breeders and scientists. Accordingly, there is a growing list of $\mathrm{R}$ genes against viruses, and our knowledge regarding the mechanisms of $\mathrm{R}$ gene-mediated defenses has advanced considerably over the last decade. However, in comparison with $\mathrm{R}$ genes against non-viral pathogens, the number of well-studied examples of antiviral $\mathrm{R}$ genes is still limited with respect to an understanding of the level of specialization of dominant resistance against viruses and the boundaries of features shared with non-viral ETI. Even more limited is our understanding of viral PTI in plants. Recent studies have provided insights into plant viral PTI. For example, it is now known that several components of bacterial and fungal PTI participate also in viral PTI. These include the co-receptor SERKs, BAK1 and SERK1, and the MAPK4 negative regulator, in addition to common effects of non-viral PTI that are also elicited during virus infection. Nevertheless, our knowledge about the dynamics between the virulence strategy of viruses and the plant immune system is still rudimentary, and several steps in the mechanism of antiviral innate immunity are still unknown. Indeed, although non-self RNA motifs appear to function as PAMPs from RNA viruses, we do not know the identities of virus-derived PAMPs or plant-derived DAMPs that would induce antiviral PTI. The repertoire of viral suppressors of PTI is limited to the CP from PPV and perhaps to NSP from begomoviruses. Furthermore, antiviral PRRs have not been identified, and mechanisms by which intracellular pathogens that have no access to the apoplast are sensed extracellularly

\section{REFERENCES}

Aarts, N., Metz, M., Holub, E., Staskawicz, B. J., Daniels, M. J., and Parker, J. E. (1998). Different requirements for EDS1 and NDR1 by disease resistance genes define at least two R gene-mediated signaling pathways in Arabidopsis. Proc. Natl. Acad. Sci. U.S.A. 95, 10306-10311. doi: 10.1073/pnas.95.17.10306

Anagnostou, K., Jahn, M., and Perl-Treves, R. (2000). Inheritance and linkage analysis of resistance to Zucchini yellow mosaic virus, Watermelon mosaic virus, Papaya ringspot virus and powdery mildew in melon. Euphytica 116, 265-270. doi: 10.1023/A:1004005716806

Balachandran, S., Roberts, P. C., Brown, L. E., Truong, H., Pattnaik, A. K., Archer, D. R., et al. (2000). Essential role for the dsRNA-dependent protein kinase PKR in innate immunity to viral infection. Immunity 13, 129-141. doi: 10.1016/ S1074-7613(00)00014-5

Bartels, S., and Boller, T. (2015). Quo vadis, Pep? Plant elicitor peptides at the crossroads of immunity, stress, and development. J. Exp. Bot. 66, 5183-5193. doi: $10.1093 /$ jxb/erv180

Bendahmane, A., Kanyuka, K., and Baulcombe, D. C. (1999). The Rx gene from potato controls separate virus resistance and cell death responses. Plant Cell 11, 781-791. doi: 10.1105/tpc.11.5.781

Bendahmane, A., Köhm, B. A., Dedi, C., and Baulcombe, D. C. (1995). The coat protein of potato virus $\mathrm{X}$ is a strain-specific elicitor of Rxl-mediated are unknown. A better understanding of the repertoire of virus effectors (Avr factor) and NB-LRR host targets (R proteins) and their mode of action in activating ETI and/or suppressing PTI will help to define the evolutionary pressure acting upon the host and viruses and to determine how to deploy the immune system for more efficient control of virus infection. We also need to define NIK1-mediated suppression of translation as a general or virus-specific antiviral strategy in plants. To date, a sustained NIK1 pathway has been shown to be effective against begomoviruses, one of the largest groups of plant DNA viruses, which cannot circumvent the regulatory mechanism of host translation. In this regard, the intrinsic capacity of agronomically relevant crops to withstand the deleterious effects of suppression of global translation must be considered as a relevant agronomic trait if we are to use the translational control branch of NIK1-mediated antiviral signaling for crop protection against begomoviruses.

\section{AUTHOR CONTRIBUTIONS}

BG and IC wrote the first draft of the manuscript; JM wrote the ETI section; AS edited the manuscript and EF edited the manuscript.

\section{ACKNOWLEDGMENTS}

This work was supported by the Conselho Nacional de Desenvolvimento Científico e Tecnológico [573600/2008-2 and 447578/2014-6 to E.P.B.F.) and the Fundação de Amparo à Pesquisa do Estado de Minas Gerais [CBB-APQ-03175-13 and CBB-APQ-01491-14 to EF]. BG and IC were supported by $\mathrm{CNPq}$ graduate fellowships, and $\mathrm{JM}$ is a recipient of a CAPES postdoctoral fellowship.

virus resistance in potato. Plant J. 8, 933-941. doi: 10.1046/j.1365-313X.1995. 8060933.x

Bendahmane, A., Querci, M., Kanyuka, K., and Baulcombe, D. C. (2000). Agrobacterium transient expression system as a tool for the isolation of disease resistance genes: application to the Rx2 locus in potato. Plant J. 21, 73-81. doi: 10.1046/j.1365-313x.2000.00654.x

Bent, A. F., and Mackey, D. (2007). Elicitors, effectors, and R genes: the new paradigm and a lifetime supply of questions. Annu. Rev. Phytopathol. 45, 399-436. doi: 10.1146/annurev.phyto.45.062806.094427

Bigeard, J., Colcombet, J., and Hirt, H. (2015). Signaling mechanisms in patterntriggered immunity (PTI). Mol. Plant. 8, 521-539. doi: 10.1016/j.molp.2014. 12.022

Boller, T., and Felix, G. (2009). A renaissance of elicitors: perception of microbeassociated molecular patterns and danger signals by pattern-recognition receptors. Annu. Rev. Plant Biol. 60, 379-406. doi: 10.1146/annurev.arplant.57. 032905.105346

Bonardi, V., Cherkis, K., Nishimura, M. T., and Dangl, J. L. (2012). A new eye on NLR proteins: focused on clarity or diffused by complexity? Curr. Opin. Immunol. 24, 41-50. doi: 10.1016/j.coi.2011.12.006

Botër, M., Amigues, B., Peart, J., Breuer, C., Kadota, Y., Casais, C., et al. (2007). Structural and functional analysis of SGT1 reveals that its interaction with HSP90 is required for the accumulation of $\mathrm{Rx}$, an $\mathrm{R}$ protein 
involved in plant immunity. Plant Cell 19, 3791-3804. doi: 10.1105/tpc.107. 050427

Brommonschenkel, S. H., Frary, A., and Tanksley, S. D. (2000). The broadspectrum Tospovirus resistance gene Sw-5 of tomato is a homolog of the rootknot nematode resistance gene Mi. Mol. Plant Microbe Interact. 13, 1130-1138. doi: 10.1094/MPMI.2000.13.10.1130

Brotman, Y., Normantovich, M., Goldenberg, Z., Zvirin, Z., Kovalski, I., Stovbun, N., et al. (2013). Dual resistance of melon to Fusarium oxysporum races 0 and 2 and to Papaya ringspot virus is controlled by a pair of head-tohead- oriented NB-LRR genes of unusual architecture. Mol. Plant 6, 235-238. doi: $10.1093 / \mathrm{mp} / \mathrm{sss} 121$

Brustolini, O. J. B., Machado, J. P. B., Condori-Apfata, J. A., Coco, D., Deguchi, M., Loriato, V. A., et al. (2015). Sustained NIK-mediated antiviral signalling confers broad-spectrum tolerance to begomoviruses in cultivated plants. Plant Biotechnol. J. 13, 1300-1311. doi: 10.1111/pbi.12349

Burch-Smith, T. M., Schiff, M., Caplan, J. L., Tsao, J., Czymmek, K., and DineshKumar, S. P. (2007). A novel role for the TIR domain in association with pathogen-derived elicitors. PLoS Biol. 5:e68. doi: 10.1371/journal.pbio.0050068

Butterbach, P., Verlaan, M. G., Dullemans, A., Lohuis, D., Visser, R. G. F., Bai, Y., et al. (2014). Tomato yellow leaf curl virus resistance by Ty-1 involves increased cytosine methylation of viral genomes and is compromised by Cucumber mosaic virus infection. Proc. Natl. Acad. Sci. U.S.A. 111, 12942-12947. doi: 10.1073/ pnas. 1400894111

Candresse, T., Marais, A., Faure, C., Dubrana, M. P., Gombert, J., and Bendahmane, A. (2010). multiple coat protein mutations abolish recognition of Pepino mosaic potexvirus (PepMV) by the potato rx resistance gene in transgenic tomatoes. Mol. Plant Microbe Interact. 23, 376-383. doi: 10.1094/ MPMI-23-4-0376

Caplan, J. L., Mamillapalli, P., Burch-Smith, T. M., Czymmek, K., and DineshKumar, S. P. (2008). Chloroplastic protein NRIP1 mediates innate immune receptor recognition of a viral effector. Cell 132, 449-462. doi: 10.1016/j.cell. 2007.12.031

Carr, J. P., Lewsey, M. G., and Palukaitis, P. (2010). Chapter3 - signaling in induced resistance. Adv. Virus Res. 76, 57-121. doi: 10.1016/S0065-3527(10) 76003-6

Carvalho, C. M., Santos, A. A., Pires, S. R., Rocha, S. R., Saraiva, D. I., Machado, J. P., et al. (2008). Regulated nuclear trafficking of rpL10A mediated by NIK1 represents a defense strategy of plant cells against viruses. PLoS Pathog. 4:e1000247. doi: 10.1371/journal.ppat.1000247

Chandra-Shekara, A. C., Navarre, D., Kachroo, A., Kang, H.-G., Klessig, D., and Kachroo, P. (2004). Signaling requirements and role of salicylic acid in HRTand rrt-mediated resistance to Turnip crinkle virus in Arabidopsis. Plant J. 40, 647-659. doi: 10.1111/j.1365-313X.2004.02241.x

Chinchilla, D., Zipfel, C., Robatzek, S., Kemmerling, B., Nürnberger, T., Jones, J. D., et al. (2007). A flagellin-induced complex of the receptor FLS2 and BAK1 initiates plant defence. Nature 448, 497-500. doi: 10.1038/nature 05999

Chisholm, S. T., Mahajan, S. K., Whitham, S. A., Yamamoto, M. L., and Carrington, J. C. (2000). Cloning of the Arabidopsis RTM1 gene, which controls restriction of long-distance movement of Tobacco etch virus. Proc. Natl. Acad. Sci. U.S.A. 97, 489-494. doi: 10.1073/pnas.97.1.489

Chu, M., Desvoyes, B., Turina, M., Noad, R., and Scholthof, H. B. (2000). Genetic dissection of Tomato bushy stunt virus p19-protein-mediated host-dependent symptom induction and systemic invasion. Virology 266, 79-87. doi: 10.1006/ viro.1999.0071

Cole, A. B., Király, L., Ross, K., and Schoelz, J. E. (2001). Uncoupling resistance from cell death in the hypersensitive response of Nicotiana species to cauliflower mosaic virus infection. Mol. Plant Microbe Interact. 14, 31-41. doi: 10.1094/ MPMI.2001.14.1.31

Coll, N. S., Epple, P., and Dangl, J. L. (2011). Programmed cell death in the plant immune system. Cell Death Differ. 18, 1247-1256. doi: 10.1038/cdd.2011.37

Cooley, M. B., Pathirana, S., Wu, H. J., Kachroo, P., and Klessig, D. F. (2000). Members of the Arabidopsis HRT/RPP8 family of resistance genes confer resistance to both viral and oomycete pathogens. Plant Cell 12, 663-676. doi: 10.1105/tpc.12.5.663

Culver, J. N., and Padmanabhan, M. S. (2007). Virus-induced disease: altering host physiology one interaction at a time. Annu. Rev. Phytopathol. 45, 221-243. doi: 10.1146/annurev.phyto.45.062806.094422
Dangl, J. L., Horvath, D. M., and Staskawicz, B. J. (2013). Pivoting the plant immune system from dissection to deployment. Science 341, 746-751. doi: $10.1126 /$ science. 1236011

Dangl, J. L., and Jones, J. D. (2001). Plant pathogens and integrated defence responses to infection. Nature 411, 826-833. doi: 10.1038/35081161

de Ronde, D., Butterbac, P., and Kormelink, R. (2014). Dominant resistance against plant viruses. Front. Plant Sci. 5:307. doi: 10.3389/fpls.2014.00307

Decroocq, V., Salvador, B., Sicard, O., Glasa, M., Cosson, P., Svanella-Dumas, L., et al. (2009). The determinant of potyvirus ability to overcome the RTM resistance of Arabidopsis thaliana maps to the N-terminal region of the coat protein. Mol. Plant Microbe Interact. 22, 1302-1311. doi: 10.1094/MPMI-2210- 1302

Dodds, P. N., and Rathjen, J. P. (2010). Plant immunity: towards an integrated view of plant-pathogen interactions. Nat. Rev. Genet. 11, 539-548. doi: 10.1038/ $\operatorname{nrg} 2812$

Erickson, F. L., Holzberg, S., Calderon-Urrea, A., Handley, V., Axtell, M., Corr, C., et al. (1999). The helicase domain of the TMV replicase proteins induces the $\mathrm{N}$-mediated defense response in tobacco. Plant J. 18, 67-75. doi: 10.1046/j. 1365-313X.1999.00426.x

Falk, A., Feys, B. J., Frost, L. N., Jones, J. D. G., Daniels, M. J., and Parker, J. E. (1999). EDS1, an essential component of R gene-mediated disease resistance in Arabidopsis has homology to eukaryotic lipases. Proc. Natl. Acad. Sci. U.S.A. 96, 3292-3297. doi: 10.1073/pnas.96.6.3292

Farnham, G., and Baulcombe, D. C. (2006). Artificial evolution extends the spectrum of viruses that are targeted by a disease-resistance gene from potato. Proc. Natl. Acad. Sci. U.S.A. 103, 18828-18833. doi: 10.1073/pnas.0605777103

Feys, B. J., Moisan, L. J., Newman, M. A., and Parker, J. E. (2001). Direct interaction between the Arabidopsis disease resistance signaling proteins, EDS1 and PAD4. EMBO J. 20, 5400-5411. doi: 10.1093/emboj/20.19.5400

Feys, B. J., Wiermer, M., Bhat, R. A., Moisan, L. J., Medina-Escobar, N., Neu, C., et al. (2005). Arabidopsis SENESCENCE- ASSOCIATED GENE101 stabilizes and signals within an ENHANCED DISEASE SUSCEPTIBILITY1 complex in plant innate immunity. Plant Cell 17, 2601-2613. doi: 10.1105/tpc.105.033910

Flor, H. (1971). Current status of the gene-for-gene concept. Annu. Rev. Phytopathol. 9, 275-296. doi: 10.1146/annurev.py.09.090171.001423

Fontes, E. P. B., Santos, A. A., Luz, D. F., Waclawovsky, A. J., and Chory, J. (2004). The geminivirus nuclear shuttle protein is a virulence factor that suppresses transmembrane receptor kinase activity. Genes Dev. 18, 2545-2556. doi: 10. $1101 /$ gad.1245904

Garrido-Ramirez, E. R., and Gilbertson, R. L. (1998). First report of tomato mottle geminivirus infecting tomato in Yucatan, Mexico. Plant Dis. 82:592. doi: 10. 1094/PDIS.1998.82.5.592B

Goelet, P., Lomonossoff, G. P., Butler, P. J., Akam, M. E., Gait, M. J., and Karn, J. (1982). Nucleotide sequence of tobacco mosaic virus RNA. Proc. Natl. Acad. Sci. U.S.A. 79, 5818-5822. doi: 10.1073/pnas.79.19.5818

Hallwass, M., de Oliveira, A. S., de Campos Dianese, E., Lohuis, D., Boiteux, L. S., Inoue-Nagata, A. K., et al. (2014). The Tomato spotted wilt virus cell-to-cell movement protein (NS) triggers a hypersensitive response in Sw-5-containing resistant tomato lines and in Nicotiana benthamiana transformed with the functional Sw-5b resistance gene copy. Mol. Plant Pathol. 15, 871-880. doi: 10.1111/mpp.12144

Hao, W., Collier, S. M., Moffett, P., and Chai, J. (2013). Structural basis for the interaction between the potato virus $\mathrm{X}$ resistance protein $(\mathrm{Rx})$ and its cofactor Ran GTPase-activating protein 2 (RanGAP2). J. Biol. Chem. 288, 35868-35876. doi: 10.1074/jbc.M113.517417

Hayes, A. J., Jeong, S. C., Gore, M. A., Yu, Y. G., Buss, G. R., Tolin, S. A., et al. (2004). Recombination within a nucleotide-binding-site/leucine-richrepeat gene cluster produces new variants conditioning resistance to Soybean mosaic virus in soybeans. Genetics 166, 493-503. doi: 10.1534/genetics.166.1.493

Heese, A., Hann, D. R., Gimenez-Ibanez, S., Jones, A. M., He, K., Li, J., et al. (2007). The receptor-like kinase SERK3/BAK1 is a central regulator of innate immunity in plants. Proc. Natl. Acad. Sci. U.S.A. 104, 12217-12222. doi: 10.1073/pnas. 0705306104

Hogenhout, S. A., van der Hoorn, R. A. L., Terauchi, R., and Kamoun, S. (2009). Emerging concepts in effector biology of plant-associated organisms. Mol. Plant Microbe Interact. 22, 115-122. doi: 10.1094/mpmi-22-2-0115

Holmes, F. O. (1929). Local lesions in tobacco mosaic. Bot. Gaz. 87, 39-55. doi: $10.1086 / 333923$ 
Holmes, F. O. (1938). Inheritance of resistance to tobacco-mosaic disease in tobacco. Phytopathology 28, 553-561.

Hoser, R., Lichocka, M., Zurczak, M., Hennig, J., and Krzymowska, M. (2014). Emerging role of SGT1 as a regulator of NB-LRR-receptor nucleocytoplasmic partitioning. Plant Signal. Behav. 9:e28724. doi: 10.4161/psb.28724

Hoser, R., Zurczak, M., Lichocka, M., Zuzga, S., Dadlez, M., Samuel, M. A., et al. (2013). Nucleocytoplasmic partitioning of tobacco $\mathrm{N}$ receptor is modulated by SGT1. New Phytol. 200, 158-171. doi: 10.1111/nph.12347

Howden, A. J., and Huitema, E. (2012). Effector-triggered post-translational modifications and their role in suppression of plant immunity. Front. Plant Sci. 3:160. doi: $10.3389 /$ fpls.2012.00160

Huisman, M. J., Linthorst, H. J., Bol, J. F., and Cornelissen, J. C. (1988). The complete nucleotide sequence of potato virus $\mathrm{X}$ and its homologies at the amino acid level with various plus-stranded RNA viruses. J. Gen. Virol. 69, 1789-1798. doi: 10.1099/0022-1317-69-8-1789

Iriti, M., and Varoti, E. M. (2014). Chitosan-induced antiviral activity and innate immunity in plants. Environ. Sci. Pollut. Res. Int. 22, 2935-2944. doi: 10.1007/ s11356-014-3571-7

Ishibashi, K., and Ishikawa, M. (2013). The resistance protein Tm-1 inhibits formation of a Tomato mosaic virus replication protein-host membrane protein complex. J. Virol. 87, 7933-7939. doi: 10.1128/JVI.00743-13

Ishibashi, K., and Ishikawa, M. (2014). Mechanisms of Tomato mosaic virus RNA replication and its inhibition by the host resistance factor Tm-1. Curr. Opin. Virol. 9, 8-13. doi: 10.1016/j.coviro.2014.08.005

Ishibashi, K., Kezuka, Y., Kobayashi, C., Kato, M., Inoue, T., Nonaka, T., et al. (2014). Structural basis for the recognition-evasion arms race between Tomato mosaic virus and the resistance gene Tm-1. Proc. Natl. Acad. Sci. U.S.A. 111, e3486-e3495. doi: 10.1073/pnas.1407888111

Ishibashi, K., Masuda, K., Naito, S., Meshi, T., and Ishikawa, M. (2007). An inhibitor of viral RNA replication is encoded by a plant resistance gene. Proc. Natl. Acad. Sci. U.S.A. 104, 13833-13838. doi: 10.1073/pnas.0703203104

Ishibashi, K., Mawatari, N., Miyashita, S., Kishino, H., Meshi, T., and Ishikawa, M. (2012). Coevolution and hierarchical interactions of Tomato mosaic virus and the resistance gene Tm-1. PLoS Pathog. 8:e1002975. doi: 10.1371/journal.ppat. 1002975

Ishibashi, K., Naitob, S., Meshia, T., and Ishikawa, M. (2009). An inhibitory interaction between viral and cellular proteins underlies the resistance of tomato to non adapted tobamoviruses. Proc. Natl. Acad. Sci. U.S.A. 106, 8778-8783. doi: 10.1073/pnas.0809105106

Jones, J. D. G., and Dangl, J. L. (2006). The plant immune system. Nature 444, 323-329. doi: 10.1038/nature05286

Kadota, Y., and Shirasu, K. (2012). The HSP90 complex of plants. Biochim. Biophys. Acta 1823, 689-697. doi: 10.1016/j.bbamcr.2011.09.016

Kadota, Y., Sklenar, J., Derbyshire, P., Stransfeld, L., Asai, S., Ntoukakis, V., et al. (2014). Direct Regulation of the NADPH Oxidase RBOHD by the PRRAssociated Kinase BIK1 during Plant Immunity. Mol. Cell 54, 43-55. doi: 10. 1016/j.molcel.2014.02.021

Kato, M., Ishibashi, K., Kobayashi, C., Ishikawa, M., and Katoh, E. (2013). Expression, purification, and functional characterization of an N-terminal fragment of the Tomato mosaic virus resistance protein Tm-1. Protein Expr. Purif. 89, 1-6. doi: 10.1016/j.pep.2013.02.001

Kim, S.-B., Kang, W. H., Huy, H. N., Yeom, S. I., An, J. T., Kim, S., et al. (2016). Divergent evolution of multiple virus-resistance genes from a progenitor in Capsicum spp. New Phytol. doi: 10.1111/nph.14177 [Epub ahead of print].

Kim, S.-B., Lee, H.-Y., Seo, S., Lee, J. H., and Choi, D. (2015). RNA-dependent RNA polymerase (NIb) of the potyviruses is an avirulence factor for the broadspectrum resistance gene Pvr4 in Capsicum annuum cv. CM334. PLoS ONE 10:e0119639. doi: 10.1371/journal.pone.0119639

Kørner, C. J., Klauser, D., Niehl, A., Dominguez-Ferreras, A., Chinchilla, D., Boller, T., et al. (2013). The immunity regulator BAK1 contributes to resistance against diverse RNA viruses. Mol. Plant Microbe Interact. 26, 1271-1280. doi: 10.1094/MPMI-06-13-0179-R

Lanfermeijer, F. C., Dijkhuis, J., Sturre, M. J., de Haan, P., and Hille, J. (2003). Cloning and characterization of the durable Tomato mosaic virus resistance gene Tm-222 from Lycopersicon esculentum. Plant Mol. Biol. 52, 1037-1049. doi: 10.1023/A:1025434519282

Li, L., Li, M., Liping, Y., Zhou, Z., Liang, X., Liu, Z., et al. (2014). The FLS2associated kinase BIK1 directly phosphorylates the NADPH oxidase RbohD to control plant immunity. Cell Host Microbe 15, 329-338. doi: 10.1016/j.chom. 2014.02.009

Liu, J. Z., Horstman, H. D., Braun, E., Graham, M. A., Zhang, C., Navarre, D., et al. (2011). Soybean homologs of MPK4 negatively regulate defense responses and positively regulate growth and development. Plant Physiol. 157, 1363-1378. doi: $10.1104 /$ pp.111.185686

Liu, Y., Burch-Smith, T., Schiff, M., Feng, S., and Dinesh-Kumar, S. P. (2004). Molecular chaperone $\mathrm{Hsp} 90$ associates with resistance protein $\mathrm{N}$ and its signaling proteins SGT1 and Rar1 to modulate an innate immune response in plants. J. Biol. Chem. 279, 2101-2108. doi: 10.1074/jbc.M310029200

Ma, J. F., Hou, X. L., Xiao, D., Qi, L., Wang, F., Sun, F. F., et al. (2010). Cloning and characterization of the BcTuR3 gene related to resistance to Turnip mosaic virus (TuMV) from non-heading chinese cabbage. Plant Mol. Biol. Rep. 28, 588-596. doi: 10.1007/s11105-010-0183-3

Ma, X., Xu, G., He, P., and Shan, L. (2016). SERKing coreceptors for receptors. Plant Sci. 21, 1017-1033. doi: 10.1016/j.tplants.2016.08.014

Machado, J. P. B., Brustolini, O. J. B., Mendes, G. C., Santos, A. A., and Fontes, E. P. B. (2015). NIK1, a host factor specialized in antiviral defense or a novel general regulator of plant immunity? Bioessays 37, 1236-1242. doi: 10.1002/bies. 201500066

Macho, A. P., and Zipfel, C. (2014). Plant PRRs and the activation of innate immune signaling. Mol. Cell 54, 263-272. doi: 10.1016/j.molcel.2014.03.028

Maiti, S., Paul, S., and Pal, A. (2012). Isolation, characterization, and structure anal- ysis of a non-TIR-NBS-LRR encoding candidate gene from MYMIVresistant Vigna mungo. Mol. Biotechnol. 52, 217-233. doi: 10.1007/s12033-0119488-1

Mandadi, K. K., and Scholthof, K.-B. G. (2012). Characterization of a viral synergism in the monocot Brachypodium reveals distinctly altered host molecular processes associated with disease. Plant Physiol. 160, 1432-1452. doi: 10.1104/pp.112.204362

Mandadi, K. K., and Scholthof, K. B. G. (2013). Plant immune responses against viruses: How does a virus cause disease? Plant Cell 25, 1489-1505. doi: 10.1105/ tpc. 113.111658

Margaria, P., Ciuffo, M., Pacifico, D., and Turina, M. (2007). Evidence that the nonstructural protein of Tomato spotted wilt virus is the avirulence determinant in the interaction with resistant pepper carrying the Tsw gene. Mol. Plant Microbe Interact. 20, 547-558. doi: 10.1094/MPMI-20-5-0547

Mariano, A. C., Andrade, M. O., Santos, A. A., Carolino, S. M. B., Oliveira, M. L., Baracat-Pereira, M. C., et al. (2004). Identification of a novel receptor-like protein kinase that interacts with a geminivirus nuclear shuttle protein. Virology 318, 24-31. doi: 10.1016/j.virol.2003.09.038

Mbengue, M., Bourdais, G., Gervasi, F., Beck, M., Zhou, J., Spallek, T., et al. (2016). Clathrin-dependent endocytosis is required for immunity mediated by pattern recognition receptor kinases. Proc. Natl. Acad. Sci. U.S.A. 113, 11034-11039. doi: $10.1073 /$ pnas. 1606004113

Mestre, P., and Baulcombe, D. C. (2006). Elicitor-mediated oligomerization of the tobacco N disease resistance protein. Plant Cell 18, 491-501. doi: 10.1105/tpc. 105.037234

Mur, L. A. J., Kenton, P., Lloyd, A. J., Ougham, H., and Prats, E. (2008). The hypersensitive response; the centenary is upon us but how much do we know? J. Exp. Bot. 59, 501-520. doi: 10.1093/jxb/erm239

Nicaise, V. (2014). Crop immunity against viruses: outcomes and future challenges. Front. Plant Sci. 5:660. doi: 10.3389/fpls.2014.00660

Nicaise, V., and Candresse, T. (2016). Plum pox virus capsid protein suppresses plant pathogen-associated molecular pattern (PAMP)-triggered immunity. Mol. Plant Pathol. doi: 10.1111/mpp.12447 [Epub ahead of print].

Niehl, A., Wyrsch, I., Boller, T., and Heinlein, M. (2016). Double-stranded RNAs induce a pattern-triggered immune signaling pathway in plants. New Phytol. 211, 1008-1019. doi: 10.1111/nph.13944

Osman, T. A., and Buck, K. W. (1996). Complete replication in vitro of tobacco mosaic virus RNA by a template-dependent, membrane-bound RNA polymerase. J. Virol. 70, 6227-6234.

Oßwald, W., Fleischmann, F., Rigling, D., Coelho, A. C., Cravador, A., Diez, J., et al. (2014). Strategies of attack and defence in woody plant-Phytophthora interactions. For. Pathol. 44, 169-190. doi: 10.1111/efp.12096

Padgett, H. S., Watanabe, Y., and Beachy, R. N. (1997). Identification of the TMV replicase sequence that activates the $\mathrm{N}$ gene-mediated hypersensitive response. Mol. Plant Microbe Interact. 10, 709-715. doi: 10.1094/MPMI.1997.10.6.709 
Padmanabhan, M. S., Ma, S., Burch-Smith, T. M., Czymmek, K., Huijser, P., and Dinesh-Kumar, S. P. (2013). Novel positive regulatory role for the SPL6 transcription factor in the $\mathrm{N}$ TIR-NB-LRR receptor-mediated plant innate immunity. PLoS Pathog. 9:e1003235. doi: 10.1371/journal.ppat.1003235

Pallas, V., and García, J. A. (2011). How do plant viruses induce disease? Interactions and interference with host components. J. Gen. Virol. 92, 2691-2705. doi: 10.1099/vir.0.034603-0

Peiro, A., Canizares, M. C., Rubio, L., Lopez, C., Moriones, E., Aramburu, J., et al. (2014). The movement protein (NSm) of Tomato spotted wilt virus is the avirulence determinant in the tomato Sw-5 gene-based resistance. Mol. Plant Pathol. 15, 802-813. doi: 10.1111/mpp.12142

Postma, J., Liebrand, T. W., Bi, G., Evrard, A., Bye, R. R., Mbengue, M., et al. (2016). Avr4 promotes Cf- 4 receptor-like protein association with the BAK1/SERK3 receptor-like kinase to initiate receptor endocytosis and plant immunity. New Phytol. 210, 627-642. doi: 10.1111/nph.13802

Rairdan, G. J., Collier, S. M., Sacco, M. A., Baldwin, T. T., Boettrich, T., and Moffett, P. (2008). The coiled-coil and nucleotide binding domains of the potato rx disease resistance protein function in pathogen recognition and signaling. The Plant Cell 20, 739-751. doi: 10.1105/tpc.107.056036

Reimer-Michalski, E. M., and Conrath, U. (2016). Innate immune memory in plants. Semin. Immunol. 4, 319-327. doi: 10.1016/j.smim.2016.05.006

Ren, T., Qu, F., and Morris, T. J. (2000). HRT gene function requires interaction between a NAC protein and viral capsid protein to confer resistance to Turnip crinkle virus. Plant Cell 12, 1917-1926. doi: 10.1105/tpc.12.10.1917

Rocha, C. S., Santos, A. A., Machado, J. P. B., and Fontes, E. P. B. (2008). The ribosomal protein L10/QM-like protein is a component of the NIK-mediated antiviral signaling. Virology 380, 165-169. doi: 10.1016/j.virol.2008.08.005

Ronde, D., Butterbach, P., Lohuis, D., Hedil, M., van Lent, J. W., and Kormelink, R. (2013). Tsw gene- based resistance is triggered by a functional RNA silencing suppressor protein of the Tomato spotted wilt virus. Mol Plant Pathol. 14, 405-415. doi: 10.1111/mpp.12016

Ronde, D., Pasquier, A., Ying, S., Butterbach, P., Lohuis, D., and Kormelink, R. (2014). Analysis of Tomato spotted wilt virus NSs protein indicates the importance of the N-terminal domain for avirulence and RNA silencing suppression. Mol. Plant Pathol. 15, 185-195. doi: 10.1111/mpp. 12082

Ross, A. F. (1961). Systemic acquired resistance induced by localized virus infections in plants. Virology 14, 340-358. doi: 10.1016/0042-6822(61) 90318-X

Roux, F., Voisin, D., Badet, T., Balagué, C., Barlet, X., Huard-Chauveau, C., et al. (2014). Resistance to phytopathogens e tutti quanti: placing plant quantitative disease resistance on the map. Mol. Plant Pathol. 15, 427-432. doi: 10.1111/ mpp. 12138

Roux, M., Schwessinger, B., Albrecht, C., Chinchilla, D., Jones, A., Holton, N., et al. (2011). The Arabidopsis leucine-rich repeat receptor-like kinases BAK1/SERK3 and BKK1/SERK4 are required for innate immunity to hemibiotrophic and biotrophic pathogens. Plant Cell 23, 2440-2455. doi: 10.1105/tpc.111. 084301

Sakamoto, T., Deguchi, M., Brustolini, O. J. B., Santos, A. A., Silva, F. F., and Fontes, E. P. (2012). The tomato RLK superfamily: phylogeny and functional predictions about the role of the LRRII-RLK subfamily in antiviral defense. BMC Plant Biol. 12:229. doi: 10.1186/1471-2229-12-229

Santos, A. A., Carvalho, C. M., Florentino, L. H., Ramos, H. J. O., and Fontes, E. P. (2009). Conserved threonine residues within the A-loop of the receptor NIK differentially regulate the kinase function required for antiviral signaling. PLoS ONE 4:e5781. doi: 10.1371/journal.pone.0005781

Santos, A. A., Lopes, K. V. G., Apfata, J. A. C., and Fontes, E. P. B. (2010). NSPinteracting kinase, NIK: a transducer of plant defence signalling. J. Exp. Bot. 61, 3839-3845. doi: 10.1093/jxb/erq219

Schwessinger, B., and Ronald, P. C. (2012). Plant Innate Immunity: perception of Conserved Microbial Signatures. Annu. Rev. Plant Biol. 63, 451-482. doi: 10.1146/annurev-arplant-042811-105518

Shah, K., Vervoort, J., and de Vries, S. C. (2001). Role of threonines in the Arabidopsis thaliana somatic embryogenesis receptor kinase 1 activation loop in phosphorylation. J. Biol. Chem. 276, 41263-41269. doi: 10.1074/jbc. M102381200

Slootweg, E., Roosien, J., Spiridon, L. N., Petrescu, A. J., Tameling, W., Joosten, M., et al. (2010). Nucleocytoplasmic distribution is required for activation of resistance by the potato NB-LRR receptor $\mathrm{Rx} 1$ and is balanced by its functional domains. Plant Cell 22, 4195-4215. doi: 10.1105/tpc.110.077537

Song, D. H., and Lee, J. O. (2012). Sensing of microbial molecular patterns by Tolllike receptors. Immunol. Rev. 250, 216-229. doi: 10.1111/j.1600-065X.2012. 01167.x

Spassova, M. I., Klein-Lankhorst, R. M., Hille, J., Goldbach, R. W., Prins, M., Spassova, M. I., et al. (2001). The tomato gene Sw5 is a member of the coiled coil, nucleotide binding, leucine-rich repeat class of plant resistance genes and confers resistance to TSWV in tobacco. Mol. Breed. 7, 151-161. doi: 10.1023/A: 1011363119763

Spoel, S. H., and Dong, X. (2012). How do plants achieve immunity? Defence without specialized immune cells. Nat. Rev. Immunol. 12, 89-100. doi: 10.1038/ nri3141

Sun, Y., Li, L., Macho, A. P., Han, Z., Hu, Z., Zipfel, C., et al. (2013). Structural basis for flg22-induced activation of the Arabidopsis FLS2-BAK1 immune complex. Science 342, 624-628. doi: 10.1126/science.1243825

Takahashi, H., Miller, J., Nozaki, Y., Takeda, M., Shah, J., Hase, S., et al. (2002). RCY1, an Arabidopsis thaliana RPP8/HRT family resistance gene, conferring resistance to Cucumber mosaic virus requires salicylic acid, ethylene and a novel signal transduction mechanism. Plant J. 32, 655-667. doi: 10.1046/j.1365-313X. 2002.01453.x

Takahashi, H., Suzuki, M., Natsuaki, K., Shigyo, T., Hino, K., Teraoka, T., et al. (2001). Mapping the virus and host genes involved in the resistance response in Cucumber mosaic virus infected Arabidopsis thaliana. Plant Cell Physiol. 42, 340-347. doi: 10.1093/pcp/pce039

Tameling, W. I., Nooijen, C., Ludwig, N., Boter, M., Slootweg, E., Goverse, A., et al. (2010). RanGAP2 mediates nucleocytoplasmic partitioning of the NB-LRR immune receptor $\mathrm{Rx}$ in the Solanaceae, thereby dictating $\mathrm{Rx}$ function. Plant Cell 22, 4176-4194. doi: 10.1105/tpc.110.077461

Tsuda, K., and Katagiri, F. (2010). Comparing signaling mechanisms engaged in pattern-triggered and effector-triggered immunity. Curr. Opin. Plant Biol. 13, 459-465. doi: 10.1016/j.pbi.2010.04.006

Ueda, H., Yamaguchi, Y., and Sano, H. (2006). Direct interaction between the Tobacco mosaic virus helicase domain and the ATP-bound resistance protein, $\mathrm{N}$ factor during the hypersensitive response in tobacco plants. Plant Mol. Biol. 61, 31-45. doi: 10.1007/s11103-005-5817-8

Van der Hoorn, R. A., and Kamoun, S. (2008). From Guard to Decoy: a new model for perception of plant pathogen effectors. Plant Cell 20, 2009-2017. doi: $10.1105 /$ tpc. 108.060194

Verlaan, M. G., Hutton, S. F., Ibrahem, R. M., Kormelink, R., Visser, R. G., Scott, J. W., et al. (2013). The Tomato Yellow Leaf Curl Virus resistance genes Ty-1 and Ty-3 are allelic and code for DFDGD-class RNA-dependent RNA polymerases. PLoS Genet. 9:e1003399. doi: 10.1371/journal.pgen. 1003399

Vidal, S., Cabrera, H., Andersson, R. A., Fredriksson, A., and Valkonen, J. P. (2002). Potato geneY-1 is an N gene homolog that confers cell death upon infection with potato virus Y. Mol. Plant Microbe Interact. 15, 717-727. doi: 10.1094/MPMI.2002.15.7.717

Wang, X., Goshe, M. B., Soderblom, E. J., Phinney, B. S., Kuchar, J. A., Li, J., et al. (2005). Identification and functional analysis of in vivo phosphorylation sites of the Arabidopsis BRASSINOSTEROID-INSENSITIVE1 receptor kinase. Plant Cell 17, 1685-1703. doi: 10.1105/tpc.105.031393

Wang, X., Kota, U., He, K., Blackburn, K., Li, J., Goshe, M. B., et al. (2008). Sequential transphosphorylation of the BRI1/BAK1 receptor kinase complex impacts early events in brassinosteroid signaling. Dev. Cell 15, 220-235. doi: 10.1016/j.devcel.2008.06.011

Wang, Y., Li, Z., Liu, D., Xu, J., Wei, X., Yan, L., et al. (2014). Assessment of BAK1 activity in different plant receptor-like kinase complexes by quantitative profiling of phosphorylation patterns. J. Proteomics 108, 484-493. doi: 10.1016/ j.jprot.2014.06.009

Wen, R. H., Khatabi, B., Ashfield, T., Saghai Maroof, M. A., and Hajimorad, M. R. (2013). The HC-Pro and P3 cistrons of an avirulent Soybean mosaic virus are recognized by different resistance genes at the complex Rsv1 locus. Mol. Plant Microbe Interact. 26, 203-215. doi: 10.1094/MPMI-06-12-0156- R

Whitham, S., Dineshkumar, S. P., Choi, D., Hehl, R., Corr, C., and Baker, B. (1994). The product of the Tobacco mosaic virus resistance gene $\mathrm{N}$ : similarity to Toll and the Interleukin-1 receptor. Cell 78, 1101-1115. doi: 10.1016/0092-8674(94) 90283-6 
Whitham, S. A., Anderberg, R. J., Chisholm, S. T., and Carrington, J. C. (2000). Arabidopsis RTM2 gene is necessary for specific restriction of Tobacco etch virus and encodes an unusual small heat shock-like protein. Plant Cell 12, 569-582. doi: $10.2307 / 3871070$

Win, J., Chaparro-Garcia, A., Belhaj, K., Saunders, D. G. O., Yoshida, K., Dong, S., et al. (2012). Effector biology of plant-associated organisms: concepts and perspectives. Cold Spring Harb. Symp. Quant. Biol. 77, 235-247. doi: 10.1101/ sqb.2012.77.015933

Yamaji, Y., Maejima, K., Komatsu, K., Shiraishi, T., Okano, Y., Himeno, M., et al. (2012). Lectin-mediated resistance impairs plant virus infection at the cellular level. Plant Cell 24, 778-793. doi: 10.1105/tpc.111.093658

Yang, H., Gou, X., He, K., Xi, D., Du, J., Lin, H., et al. (2010). BAK1 and BKK1 in Arabidopsis thaliana confer reduced susceptibility to turnip crinkle virus. Eur. J. Plant Pathol. 127, 149-156. doi: 10.1007/s10658-010-9581-5

Yang, Z., Liu, L., Fang, H., Li, P., Xu, S., Cao, W., et al. (2016). Origin of the plant Tm-1-like gene via two independent horizontal transfer events and one gene fusion event. Sci Rep. 6:33691. doi: 10.1038/srep33691

Yang, Z. N., Ye, X. R., Molina, J., Roose, M. L., and Mirkov, T. E. (2003). Sequence analysis of a 282-kilobase region surrounding the Citrus tristeza virus resistance gene (Ctv) locus in Poncirus trifoliata L. Raf. Plant Physiol. 131, 482-492. doi: $10.1104 /$ pp.011262

Yun, H. S., Bae, Y. H., Lee, Y. J., Chang, S. C., Kim, S. K., Li, J., et al. (2009). Analysis of phosphorylation of the BAK1/BRI1 complex in Arabidopsis reveals amino acid residues critical for receptor formation and activation of BR signaling. Mol Cells 27, 183-190. doi: 10.1007/s10059-009-0023-1

Zhang, X. S., Choi, J. H., Heinz, J., and Chetty, C. S. (2006). Domain-specific positive selection contributes to the evolution of Arabidopsis leucine-rich repeat receptor-like kinase (LRR RLK) genes. J. Mol. Evol. 63, 612-621. doi: 10.1007/ s00239-005-0187-z

Zhu, S., Jeong, R.-D., Venugopal, S. C., Lapchyk, L., Navarre, D., Kachroo, A., et al. (2011). SAG101 forms a ternary complex with EDS1 and PAD4 and is required for resistance signaling against Turnip crinkle virus. PLoS Pathog. 7:e1002318. doi: 10.1371/journal.ppat.1002318

Zipfel, C. (2014). Plant pattern-recognition receptors. Trends Immunol. 35, 345-351. doi: 10.1016/j.it.2014.05.004

Zorzatto, C., Machado, J. P. B., Lopes, K. V. G., Nascimento, K. J. T., Pereira, W. A., Brustolini, O. J., et al. (2015). NIK1-mediated translation suppression functions as a plant antiviral immunity mechanism. Nature 520, 679-682. doi: 10.1038 /nature 14171

Zvereva, A. S., and Pooggin, M. M. (2012). Silencing and innate immunity in plant defense against viral and non-viral pathogens. Viruses 4, 2578-2597. doi: $10.3390 / \mathrm{v} 4112578$

Conflict of Interest Statement: The authors declare that the research was conducted in the absence of any commercial or financial relationships that could be construed as a potential conflict of interest.

Copyright (c) 2017 Gouveia, Calil, Machado, Santos and Fontes. This is an openaccess article distributed under the terms of the Creative Commons Attribution License (CC BY). The use, distribution or reproduction in other forums is permitted, provided the original author(s) or licensor are credited and that the original publication in this journal is cited, in accordance with accepted academic practice. No use, distribution or reproduction is permitted which does not comply with these terms. 